\title{
THE METHODS OF MEASUREMENT OF ENTERPRISE INTERNALISATION
}

\author{
Radosław WOLNIAK \\ Politechnika Śląska, Wydział Organizacji i Zarządzania, Instytut Ekonomii i Informatyki, rwolniak@polsl.pl, \\ ORCID: 0000-0003-0317-9811
}

Purpose: The aim of the paper is to carry out analyses of the qualitative and qualitative methods of the measure of internalisation of a corporation.

Design/methodology/approach: Critical literature analysis. Analysis of international literature from main databases and Polish literature and legal acts connected with the researched topic.

Findings: In this paper, there is a description of the main methods used to measure this problem. The indicators used to measure the international level of an organisation can be divided into the following groups: structural indicators, market indicators, assessment indicators, concentration indicators and indicators of geographical and cultural distance. In the paper, there is also an example of indicators used in two internationalisation models: Uppsala model and network model. The issue of internationalisation is very promising and opens up numerous research fields. Using various methods of measuring the internationalisation of an organisation, you can then examine their associations with other methods used in the sciences regarding management of issues such as: view management, innovation, organisational culture, quality management systems maturity, etc. (after proper operationalisation of these issues).

Originality/value: Detailed analysis of methods used to measure enterprise internationalisation.

Keywords: internationalisation, internalisation measurement, internalisation models, qualitative indicators, quantitative indicators, Uppsala model, network model.

Category of the paper: literature review.

\section{Introduction}

The progressing internationalisation and globalisation of the world economy has influenced the intensification of connections between individual national economies and an increase in their interdependence. The rapidly growing process of internationalisation of enterprises is one of the characteristic features of the modern economy. The aim of this publication is to organise issues related to quantitative and qualitative methods of measuring the internationalisation of an organisation. 
The paper is the result of the project BK-231/ROZ1/2018 (13/010/BK_18/0029).

\section{Internationalisation of enterprise and their models}

Starting from the classical definition by Welch and Luostarien (Welch, and Luostarien, 1993), the authors defining the concept of internationalisation pay attention to issues related to the organisation's involvement in international operations. This type of definition is recognised by a large number of specialists dealing with the issue of internationalisation. Dicken (Dicken, 1998) thinks that the scope of such involvement is irrelevant, and even if it happened once, you can, in this situation, talk about internationalisation. Gorynia (Gorynia, and Jankowska, 2007) thinks similarly. Rugman (Rugman, 1980), on the other hand, thinks that internationalisation is only the case when an organisation conducts activities in many countries.

The analysis of definitions of internationalisation suggests that most authors believe that internationalisation is essentially connected with taking on any kind of international activities by an enterprise. In the definitions of internationalisation, there is usually a strong emphasis on undertaking business activity abroad (Wolniak, 2018; Bednarowa et. al., 2017; Olkiewicz, and Wolniak, 2018).

Internationalisation can be interpreted in a process (dynamic), institutional (static) and behavioural way. Process internationalisation is connected with its forms, such as: export, licensing, franchising, joint ventures or direct foreign investments. The institutional approach is static and is connected with relations with foreign companies without conducting direct operations outside the home country. On the other hand, behavioural internationalisation refers to attitudes and behaviours of business managers internationalising their activities (Rymarczyk, 2004; Michelle, and Byoungo, 2014).

Depending on the internationalisation method adopted, there are different models of internationalisation in literature. They can be divided into six main types, which include:

- innovative models of internationalisation,

- Uppsala model of internationalisation (stage innovation model),

- models of accelerated internationalisation,

- network model of internationalisation,

- holistic models of internationalisation,

- unconventional approaches to internationalisation.

One of the most frequently used models of internationalisation is the Uppsala model, otherwise known as the Swedish model, which derives from the works of Johanson, Wiedersheim-Paul and Vhalne. The essence of the model is the sequentiality of entering foreign markets. It is particularly characteristic of smaller countries that do not have the opportunity to achieve economies of scale. The organisation must, in this situation, slowly adapt to a foreign 
market. From this point of view, the least risky and quickly reversible form of internationalisation in the Uppsala model is export, from which enterprises most often start their presence outside the borders of their own country. Only then, in the case of the success of the export business, is it tempting to open production in a foreign country (Vahlne, 2013).

In the Uppsala model, four stages of internationalisation are distinguished:

- informal cooperation on foreign markets (lack of regular export activity),

- export by independent intermediaries (agreement with an agent representing the organisation abroad),

- establishing a branch of trade,

- establishment of a production branch abroad.

The second, very important, innovation model is the network model, which was created at the end of the 1980s. This model derives from the so-called modern network paradigm in management sciences (Czakon, 2011; Borgati, and Foster, 2003; Woźniak-Sobczak, 2015; Jabłoński, 2015; Zdziarski, 2016).

This approach is different from the previous ones, because the stage or sequentiality is of lesser importance in this case. On the other hand, horizontal cooperation ties between domestic and foreign enterprises are very important. The internationalisation process results from the possibility of developing links between organisations. A given enterprise depends on these connections, but also influences them (Yoo, and Reimann, 2017; Axelsson, and Johanson, 1992; Ellis, 2000; Ellis et al., 1992; Korhonen et al., 1996). The company starts its internationalisation activity from engaging in a network, usually a national one, which becomes a bridge to other networks. The network also facilitates overcoming barriers resulting from the size of the organisation. Participation in international networks makes it possible to combine and co-create new resources together with other network participants and gives the opportunity to achieve synergy effects in order to undertake early foreign expansion (Fletcher, 2008; Daszkiewicz, 2006, 2008; Coviello, 2006; Prashatnam, and Ypung, 2011; Madsen, 2013; Hohental et. al. 2014).

Usually, internationalisation network models assume that an enterprise is internationalising in relation to other network participants. In this case, it can do this activity in three ways (Wach, 2012; Małys, 2013):

- through international expansion, when the number of foreign network participants increases,

- through penetration, i.e. development of network connections,

- through international integration focused on establishing and expanding relations with foreign networks. 


\section{Qualitative and quantitative methods of measure of internationalisation in business}

The degree of internationalisation of enterprises is difficult to determine, because not all of them operate internationally with the same intensity. When attempting to measure the level of internationalisation of an organisation, one can approach the problem from three types of methods (Kutschker, 1999):

- quantitative methods,

- quality methods,

- integration methods.

The strategic orientation of Perlmutter (Perlmutter, 1969) and Batlett/Ghopsh's concepts is mentioned in the field of qualitative methods of measuring the internationalisation of an organisation (Beamish, 2008).

Quantitative methods concern the use of appropriate mathematical indicators. Within them, two types of methods can be distinguished (Rogaczewski, 2015):

- one-dimensional methods,

- multidimensional methods.

It is worth mentioning that some specialists doubt whether one can develop a single index well reflecting the problem of internationalisation. For example, Dunning and Lundan (Dunning, and Lundan, 2008, 2009) believe that no indicator of international enterprise activity is able to capture the right dimension for any enterprise; hence, multidimensional methods are now becoming increasingly popular. On the other hand, for example, Szymura-Tyc (SzymuraTyc, 2013) believes that attempts to use more complex internationalisation indicators to measure the internationalisation of Polish enterprises characterised by a smaller, sometimes only passive or active, but indirect involvement on the international market do not bring satisfactory results due to the lack of data necessary to calculate them. As a result, the most commonly used measures of the internationalisation index of Polish enterprises are simple structural measures. Romanowska (Romanowska, 2011) also draws attention to the limitations in the use of some indicators to the study of the internationalisation of Polish enterprises.

The analytical indicators used to measure the internationalisation level of an organisation can be divided into the following groups (Szymura-Tyc, 2013; Romanowska, 2011; Daszkiewicz, 2004; Dorrenbacher, 2000; Przybylska, 2006, Trugden, and Freeman, 2014):

- structural indicators - presenting the international involvement of a company in a given period, e.g.:

$\circ$ the number of foreign markets on which it operates,

$\circ$ the number of foreign branches, or their share in the total number of branches of the corporation, 
$\circ$ the number of non-capital forms of internationalisation (strategic alliances, franchises, license sales, co-operation agreements),

o the value of sales of foreign branches and/or its share in the value of the entire corporate sales,

o the added value abroad,

$\circ$ the number of employees abroad and/or their share in the total number of employees in the corporation,

o the value of fixed assets abroad and/or its share in the value of the assets of the entire corporation,

- market indicators - measure the degree of an organisation's success or failure on foreign markets in a given period,

- assessment indicators - related to the foreign experience of the main corporate managers,

- concentration indicators (Małys, 2013):

○ for a homogeneous or differentiated distribution of foreign assets,

$\circ$ for the scope to which the regional distribution index of a given enterprise corresponds to such an indicator in the world,

- network expansion indicators (Pera, 2017):

$\circ$ network spread (the number of countries in which the organisation has its own branches),

0 the amount of assets and assets located outside the country,

- indicators of geographical and cultural distance (Piaskowska, 2017):

- geographical and cultural distance of partner countries from the country where the mother company is based,

- psychological distance - the number of zones in terms of differences in management in relation to the company's location country.

Analysing the indicators that can be used to analyse internationalisation processes, the previously described models of internationalisation, in particular innovative, staged and network models, were taken as a starting point. Table 1 presents a set of indicators that can be used to measure internationalisation from the perspective of a given model.

Table 1.

Indicators of measuring internationalisation from the point of view of its models

\begin{tabular}{|l|ll|}
\hline \multicolumn{1}{|c|}{ Models } & & \multicolumn{1}{c|}{ Indicators } \\
\hline & $\bullet \quad$ export, \\
Sequential model - & - & export share in sales, \\
innovative and & - internationalisation of marketing and production, \\
Uppsala model & - $\quad$ the length of the export experience, \\
& - length and type of foreign markets served, \\
& - the number and distance of physical and mental separation from the home country, \\
& - $\quad$ organisational forms and structures. \\
\hline
\end{tabular}


Cont. table 1.

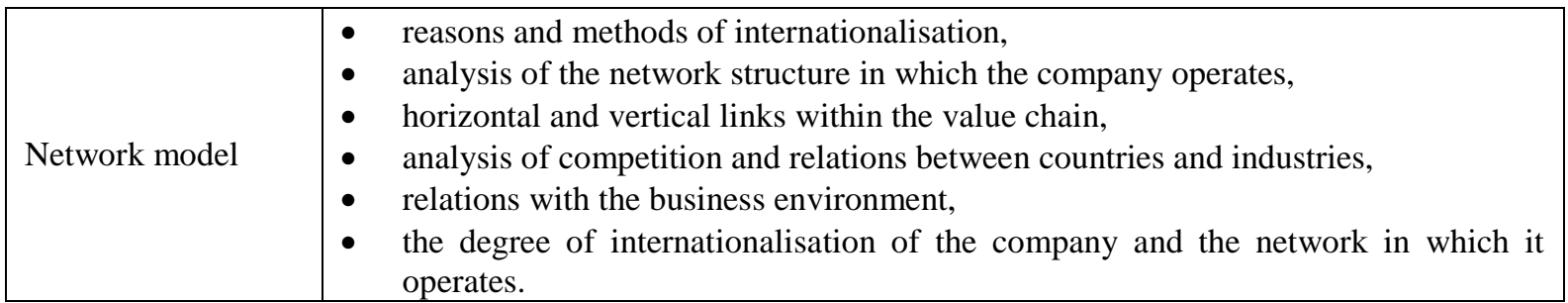

Source: Own work based on: (Bilkey and tesar, 1977; Hakanson and Johanson, 1992; Szymura-Tyc, 2013; Gulitai et al., 2000; Zuchell and Scabini, 2007).

Another division of internationalisation indicators was proposed by Karasiewicz. He identified the following six groups of internationalisation indicators (Karasiewicz, 2013):

- simple indicators (based on profit, sales, taxes),

- indicators based on the scope of activity (e.g. number of countries),

- index indicators,

- indicators based on the degree of concentration (e.g. indicator based on geographical entropy),

- indicators based on the degree of country diversity,

- indicators based on activity in the value chain.

The next group of indicators used to measure the functioning of corporations is synthetic indicators. There are a lot of these indicators, and it is difficult to discuss all that appear in literature on the subject. Selected synthetic indicators are summarised in Table 2. It presents the enterprise internationalisation index, the corporate network coverage index and the internationalisation rate of the corporation.

Table 2.

Synthetic indicators of internationalisation measurement

\begin{tabular}{|l|l|}
\hline \multicolumn{1}{|c|}{ Indicator } & $\begin{array}{l}\text { Characteristic } \\
\text { This has been developed and is published annually by UNCTAD. It is a kind of ranking } \\
\text { of international corporations. The index adopts values from the range of 1, in the case of } \\
\text { organisations operating on the domestic market, specialising only in one element of the } \\
\text { supply chain, up to 50, in the case of transnational organisations that have strongly } \\
\text { diversified international staff and activities throughout the supply chain. } \\
\text { - it consists of three elements: ITA - the ratio of the value of foreign corporation assets } \\
\text { to its total assets, } \\
\text { Index TNI }\end{array}$ \\
$\begin{array}{l}\text { sales transnationalisation index (ITS) - the sales quotient of foreign branches to the } \\
\text { total value of corporation sales, } \\
\text { employment transnationalisation index (ITZ) - the ratio of the number of employees } \\
\text { in foreign branches to total employment in a given corporation. }\end{array}$ \\
\hline $\begin{array}{l}\text { Network Spread } \\
\text { Index NSI }\end{array}$ & $\begin{array}{l}\text { The indicator takes into account the geographical distribution of foreign branches of } \\
\text { corporations. It is expressed in the ratio of the number of countries in which the } \\
\text { corporation has branches or branches to the number of all countries in which foreign } \\
\text { direct investments are taken, less the parent's home country. }\end{array}$ \\
\hline $\begin{array}{l}\text { Transnational } \\
\text { Activity Spread }\end{array}$ & $\begin{array}{l}\text { Index proposed by G. Ietto-Gillese. The index synthesises the dichotomous aspect and } \\
\text { aspect related to geographical dispersion. The indicator was created from the combination } \\
\text { of the transnationalisation index of the TNI corporation and the coverage index of the } \\
\text { NSI corporate network index. }\end{array}$ \\
\hline
\end{tabular}


Cont. table 2.

\begin{tabular}{|c|c|}
\hline $\begin{array}{l}\text { Degree of } \\
\text { Internationalisation } \\
\text { Scale DOI }\end{array}$ & $\begin{array}{l}\text { Indicator presented by D. Sullivan. The indicator allows one to highlight the } \\
\text { characteristics of transnational corporations. The synthetic index is a combination of } \\
\text { many variables that deal with issues such as: the structure of corporate resources, } \\
\text { the geographical structure of the location of individual branches, the strategy of } \\
\text { internationalisation. } \\
\text { The indicator adopts values from the range of } 0 \text {, which means that there is no international } \\
\text { involvement of the enterprise, up to 5, if the given organisation operates only outside its } \\
\text { own country. } \\
\text { The indicator consists of five indexes: } \\
\text { - FSTS - an index of internationalisation of corporation sales (Foreign Sales as } \\
\text { Percentage of Total Sales - percentage share of sales revenues abroad to total revenues } \\
\text { from sales). } \\
\text { - FATA - index of the internationalisation of corporation assets (Foreign Assets as } \\
\text { a Percentage of Total Assets - percentage share of foreign assets in the total assets of } \\
\text { the company). } \\
\text { - OSTS - index of the internationalisation of the corporation (Overseas Subsidiaries as } \\
\text { a Percentage of Total Subsidiaries - percentage ratio of foreign branches to all } \\
\text { branches of the corporation). } \\
\text { - TMIE (Top Manager's International Experience). } \\
\text { - PDIO (Psychic Dispersion of International Onerations) }\end{array}$ \\
\hline
\end{tabular}

Source: Own study based on: (Tobey and Kinghorn, 2008; Tseng and Chen, 2013, Ietto-Gilles and Seccomber-Hett, 1998; Ietto-Gilles, 1998; Chand and Thee; 2011; Sullivan, 1996; Mroczek-Dąbrowska, 2016; Lin and Liu, 2012).

\section{Conclusion}

Summing up the literature review concerning the methods of measuring the internationalisation of enterprises, it is worth noting the multidimensional character of the issues presented in the publication. The issue of measuring the level of internationalisation is complex and requires a detailed adaptation of the adopted indicator system to the issue it is to serve. There is no single commonly accepted method of operationalisation of internationalisation and its measurement; thus, depending on the needs, the different methods presented in this publication may be used.

In addition, it is worth noting that the issue of internationalisation is very promising and opens up numerous research fields. Using various methods of measuring the internationalisation of an organisation, you can then examine their associations with others used in the sciences regarding management of issues such as: view management, innovation, organisational culture, quality management systems maturity, etc. (after proper operationalisation of these issues). 


\section{References}

1. Axelsson, B., Johanson, J. (1992). Foreign Market Entry: The Textbook vs. The Network View. In: B. Axelsson, G. Easton (eds.), Industrial Networks: A New View of reality, London: Routledge.

2. Beamish, P. (2008). Transational Management: text, Cases and readings in Cross-Border Management. New York: McGraw-Hill.

3. Bednarova, L., Chovancova, J., Pacana, A., Ulewicz, A. (2017). The analysis of success factors in terms of adaptation of expatriates to work in international organizations. Polish Journal of Management Studies, 17, pp. 59-66.

4. Bilkey, W.J., Tesar, G. (1977). The export behaviour of smaller Winsconsin manufacturing firms. Journal of International Business Studies, 8, pp. 93-98.

5. Borgati, S., Foster, P. (2003). The Network Paradigm in Organizational Research: a Review and Typology. Journal of Management, 20, pp. 991-1013.

6. Chang, S.-J., Rhee, J.H. (2011). Rapid FDI Expansion and Firm Performance, Journal of International Business Studies, 8, pp. 979-994.

7. Coviello, N.E. (2006). The network dynamics of international new ventures. Journal of International Business Studies, 5, pp. 713-731.

8. Coviello, N.E. (2006). The resource dynamics of international new venture networks. Journal of International Entrepreunership, 4, pp. 111-132.

9. Czakon, W. (2011). Paradygmat sieciowy w naukach o zarządzaniu. Przegląd Organizacji, 1, pp. 3-6.

10. Daszkiewicz, N. (2004). Internacjonalizacja matych $i$ średnich przedsiębiorstw we współczesnej gospodarce. Gdańsk: SGP.

11. Daszkiewicz, N. (2006). Internacjonalizacja małych i średnich przedsiębiorstw w Unii Europejskiej. Ekonomika i Organizacja Przedsiębiorstw, 1, pp. 21-24.

12. Daszkiewicz, N. (2008). Konkurencyjność małych i średnich przedsiębiorstw w procesie internacjonalizacji. In: N. Daszkiewicz (ed.), Konkurencyjność. Poziom makro, mezo i mikro. Warszawa: PWN, pp. 56-67.

13. Dicken, P. (1998). Global shift: transforming the world economy. London.

14. Dörrenbächer, Ch. (2000). Measuring Corporate Internationalization: A Review of Measurement Conpcepts and Their Use. Intereconomics, 3, pp. 708-721

15. Dunning, J.H., Lundan, S.M. (2008). Multinational Enterprises and Global Economy. Chelterham-Northampton, MA: Edward Elgar.

16. Dunning, J.H., Lundan, S.M. (2009). The internalization of Corporate R\&D: A Review of the Evidence and some Policy Implications for Home Countries. Review of Policy Research, 1-2, pp. 101-133. 
17. Ellis, P. (2000). Social Ties and Foreign Market Entry. Journal of International Business Studies, 3, pp. 443-469.

18. Ellis, P., Johanson, J., Vahlne, J.E. (1992). Management of Foreign Market Entry. Scandinavian International Business Review, 4, pp. 9-27.

19. Fletcher, R. (2008). The internationalization from a network perspective: A longitudinal study. The Industrial Marketing, 8, pp. 953-964.

20. Gorynia, M., Jankowska, B. (2007). Teorie internacjonalizacji. Gospodarka Narodowa, 10, pp. 21-44.

21. Gulitai, R., Nohira, N., Zaheer, A. (2000). Strategic networks. Strategic Management Journal, 21, pp. 203-215.

22. Häkanson, Johanson, J. (1992). A model of industrial networks. In: B. Axelsson, G. Easton (eds.), Industrial networks. A view of reality (pp. 28-34). London-New York: Routledge.

23. Hohental, J., Johanson, J., Johanson, M. (2014). Network knowledge and businessrelationship value in the foreign market. International Business Review, 1, pp. 4-19.

24. Ietto-Gilles, G., Seccombe-Hett, T. (1998): What do internationalization indices measure? Research papers in international business, 6, pp. 2-25.

25. Ietto-Gillies, G. (1998). Different Conceptual Frameworks for the Assessment of Degree of Internationalizm: an Empirical analysis of Various indices for the Top 1000 transnational Corporations, Transnational Corporations, 1, pp. 17-40.

26. Jabłoński, A. (2015). Paradygmat systemowy, sieciowy i prowartościowy a konstruowanie modeli zrównoważonego biznesu przedsiębiorstw. Ekonomika $i$ Organizacja Przedsiębiorstwa, 10, pp. 19-29.

27. Karasiewicz, G. (2013). Marketingowe strategie internacjonalizacji polskich przedsiębiorstw: Podejście holistyczne. Warszawa: Wolter Kluwer.

28. Korhonen, H., Louostrainen, R., Welch, L. (1996). Internationalization of SME's: Inwardoutward Patterns and Government Policy. Management International Review, 4, pp. 315329.

29. Kutschker, M. (1999). Das intenationale Unternehmen. In: M. Kutschker (ed.), Perspektiven der internationalen Wirtschaft. Wiesbaden.

30. Lin, W., Liu, Y. (2012). Successor Characteristics, Organizational Slack, and Change in the Degree of Firm Internationalization. International Business Review, 21, pp. 89-101.

31. Madsen, T.K. (2013). Early and rapidly internationalizing ventures: similarities and differences between classification based on the original international new venture and born global literatures. Journal of International Entrepreneurship, 1, pp. 65-79.

32. Małys, Ł. (2013). Siła powiazań sieciowych $w$ procesie internacjonalizacji a wyniki przedsiębiorstwa. Warszawa: Difin. 
33. Michelle, L.Ch., Byoungo, J. (2014). Is Uppsala model valid to fashion retailers? An analysis from internationalisation patterns of fast fashion retailers. Journal of Fashion Marketing and Management, 1, pp.36-51.

34. Miller, S.R., Lavie, D., Delios, A. (2016). International Intensity, Diversity and Distance. Unpacking the Internationalization - Performance Relationship. International Business Review, 4, pp. 578-602.

35. Mroczek-Dąbrowska, K. (2016). Degree of internationalization in mesoeconomic perspective, Studia Ekonomiczne. Zeszyty Naukowe Uniwersytetu Ekonomicznego w Katowicach, 286, pp. 96-106;

36. Olkiewicz, M., Wolniak, R. (2018). The repationship between the economic developmeny of the country and food security. Rocznik Ochrona Środowiska, 10, pp. 804-818.

37. Pera, B. (2017). Miary internacjonalizacji przedsiębiorstw - przegląd wybranych koncepcji i badań. Studia Ekonomiczne. Zeszyty Naukowe Uniwersytetu Ekonomicznego w Katowicach, 319, pp. 184-198.

38. Perlmutter, H. (1969). The Tortuous Evolution of the Multinational Corporation. Columbia World Journal of Business, 1, pp. 9-18.

39. Piaskowska, D. (2017). When Distance is Good: An Upper-Echelons Perspective on the Role of Distance in Internationalization. In: A. Verbeke, J. Puck, R. van Tulder (eds.), Distance in International Business: Concept, Cost and Value (Progress in International Business Research, t. 12), Emerald Publishing Limited, pp. 403-423.

40. Prashatnam, S., Young, S. (2011). Post-Entry Speed of International New Ventures. Entrepreneurship Theory and Practice, 2, pp. 275-292.

41. Przybylska, K. (2006). Pomiar internacjonalizacji przedsiębiorska. Gospodarka Narodowa, 3, pp. 49-67.

42. Rogaczewski, R. (2015). Ważniejsze metody pomiaru globalizacji i internacjonalizacji przedsiębiorstw. Acta Universitatis Copernici, 3, pp. 59-71.

43. Romanowska, M. (2011). Grupy kapitałowe w Polsce. Strategie i struktury. Warszawa: PWE.

44. Rugman, A.M. (1980). A New Theory of the Multinational Enterprise, Internationalization vesrus Internationalization. Columbia Journal of World Business, 15, pp. 23-29.

45. Rymarczyk, J. (2004). Internacjonalizacja i globalizacja przedsiębiorstwa. Warszawa: PWE.

46. Sullivan, D. (1996). Measuring the Degree of Internationalization of a Firm: A reply. Journal of International Business Studies, 1, pp. 179-192.

47. Szymura-Tyc, M. (2013). Measuring the Degree of Firms' Internationalization at Their Early Stages of International Commitment. Journal of Economics and Management, 13, pp. 101-118. 
48. Szymura-Tyc, M. (2013). Pomiar stopnia internacjonalizacji przedsiębiorstw - współczesne podejścia teoretyczne i założenia metodologiczne. Studia Ekonomiczne, Uniwersytet Ekonomiczny w Katowicach, 172, pp. 41-54.

49. Tobey, D., Kinghorn, B.H. (2008). The Transnationality Index: Measuring the diversity advantage of transnational entrepreneurial organizations. Proceedings of Globalization \& Transnational Conference. Canada: Waterloo.

50. Trudgen, R., Freeman, S. (2014). Measuring the Performance of Born-Global Firms Throughout Their Development Process: The Roles of Initial Market Selection and Internationalization Speed. Management International Review, 54, pp. 551-579.

51. Tseng, Ch.-H., Chen, L.-T. (2013). Firm Capabilities as Moderators of Transaction Cost Factors and Subsidiary Domestic Outsourcing. Management Decision, 1, pp. 312-324.

52. UNICAD-UN (1995). New York-Genewa.

53. Vahlne, J.E. (2013). The Uppsala model on evolution of the multinational business enterprise - from internalization to coordination of networks. International Marketing Review, 3, pp. 189-210.

54. Wach, K. (2012). Europeizacja matych i średnich przedsiębiorstw: rozwój przez umiędzynarodowienie. Warszawa: PWN.

55. Welch, L.S., Luostarinen, R.K. (1993). Inward-outward connection in internationalization. Journal of International Marketing, 1, pp. 44-56.

56. Wolniak, R. (2018). Istota procesów internacjonalizacji przedsiębiorstw, Zeszyty Naukowe Politechniki Śląskiej. Seria Organizacja i Zarządzanie, 118, pp. 659-668.

57. Woźniak-Sobczak, B. (2015). Paradygmat sieciowy - mainstream w naukach zarządzania i praktyce biznesu. Prace Naukowe Uniwersytetu Ekonomicznego w Katowicach, Studium efektywności przedsiębiorstwa w sieci : perspektywa renty sieciowej, pp.19-35.

58. Yoo, D., Reimann, F. (2017). Internationalization of Developing Country Firms into Developed Countries: The Role of Host Country Knowledge-Based Assets and IPR Protection in FDI Location Choic. Journal of International Management, 3, pp. 242-254.

59. Zdziarski, M. (2016). Nurt sieciowy - w kierunku nowego paradygmatu zarządzania. Prace Naukowe Uniwersytetu Ekonomicznego we Wrocławiu, 421, pp. 657-668.

60. Zuchella, A., Scabini, P. (2007). International entrepreneurships, theoretical foundations and practices. London: Palgrave Macmillan. 